\title{
ANALISIS ANGGARAN BIAYA PRODUKSI SEBAGAI ALAT PENGENDALIAN BIAYA PADA CV. PINANG ADVERTISING TANJUNGPINANG
}

\author{
Ranti Utami Fizal \\ Program Studi S1-Akuntansi, Sekolah Tinggi Ilmu Ekonomi (STIE) Pembangunan \\ Tanjungpinang \\ fizalty97@gmail.com
}

\begin{abstract}
Abstrak: Tujuan dilaksanakannya penelitian ini adalah untuk menganalisis penyimpangan antara anggaran biaya produksi dengan realisasinya serta peranannya sebagai alat pengendalian biaya. Metode analisis data yang digunakan yaitu metode deskriptif kualitatif serta menggunakan data primer dan sekunder yaitu berupa wawancara dan laporan penyusunan anggaran pada tahun 2019 . Kemudian peneliti menganalisis anggaran biaya produksi realisasinya. Berdasarkan dari penelitian menunjukan bahwa pada CV. Pinang Advertising Tanjungpinang pada laporan penyusunan anggarannya dibuat sesederhana mungkin. Hasil dari penelitian menunjukkan bahwa anggaran biaya produksi pada CV. Pinang Advertising Tanjungpinang belum berperan baik dalam pengendalian biaya yang dimana biaya overhead pabriknya dalam penyusunan anggaran terdapat perbedaan selisih anggaran lebih kecil dibandingkan realisasinya (unfavorable).
\end{abstract}

Kata Kunci: Anggaran Biaya Produksi, Pengendalian Biaya

Abstract: The aim of this research is to analyze the deviation between the production cost budget and its realization and its role as a cost control tool. The data analysis method used is a qualitative descriptive method and uses primary data and a scholar, namely interviews and budget preparation reports in 2019. Then the researchers analyzed the budget for production costs. Based on the research shows that CV.Pinang Advertising Tanjungpinang on the budget preparation report is made as simple as possible. The results of the study showed that the production cost budget in CV.Pinang Advertising Tanjungpinang has not played a good role in cost control where the factory overhead costs in the preparation of the budget there is a difference in budget difference is smaller than its realization (unfavorable)

Keywords: production cost budget, cost control

\section{PENDAHULUAN}

Dalam menghadapi persaingan masalah yang semakin tinggi mengakibatkan perusahaan semakin harus mempunyai strategi agar memiliki daya saing tinggi dalam menghadapi persaingan global. Hanya perusahaan-perusahaan yang fleksibel dalam memenuhi kebutuhan konsumen mereka yang akan mampu bertahan dan berkembang dalam menghadapi persaingan global dan tajam. Oleh sebab itu diperlukan suatu sistem manajemen yang baik yang dapat menunjang suatu perusahaan. Tidak ada satupun perusahaan yang tidak ingin sukses dan berkembang. Untuk mencapai sukses dan berkembang, perlu ada nya suatu cara yang tepat, sistematis, dan dapat dipertanggung jawabkan.. Anggaran merupakan suatu rencana operasi yang dirumuskan dalam bentuk angka, termasuk taksiran atas pendapatan dan biaya untuk periode tertentu yang biasanya satu tahun. Anggaran juga merupakan suatu rencana kerja yang terperinci yang dinyatakan dalam satuan moneter atau lainnya yang jangka pendek biasanya satu tahun. Anggaran berfungsi 
sebagai sebagai alat perencanaan yang berhubungan dengan penetapan tujuan dan penyusunan aktivitas perusahaan yang akan datang. Setelah dilaksanakan, anggaran berfungsi sebagai alat pengendalian yaitu denga cara membandingkan antar anggaran dengan realisasinya. Penyimpanganpenyimpangan yang terjadi dianalisis dan kemudian dilakukan tindakan perbaikan jika diperlukan.

CV. Pinang Advertising merupakan salah satu perusahaan yang bergerak dibidang jasa dalam melakukan desain grafik diantaranya digital printing, advertising, sablon, dan percetakan yang ada di Tanjungpinang. Untuk menjalakan segala kegiatan usaha tersebut agar lancar maka membutuhkan dana untuk membiayainya. Dalam hal ini kebutuhan dana ditungakan dalam suatu perencanaan anggaran. Anggaran biaya produksi merupakan anggaran yang digunakan dalam membiayai seluruh kegiatan produksi persuahaan, sehingga sangat penting penyusunan anggaran yang baik dalam rangka membiayai kegiatan produksi untuk melihat sejauh man anggaran biaya produksi dan realisasinya. Dari hasil pra peneltian dan wawancara awal bahwa anggaran biaya produksi spanduk ukuran 1x5m, sticker label, stempel ukuran $4 \times 4 \mathrm{~cm}$, dan plakat kayu dengan realisasinya belum dapat memberikan dampak yang baik dalam melakukan perencanaan anggaran produksinya karena masih terdapat selisih yang cukup besar antara anggaran biaya produksi dengan realisasinya, maka berakibat pada berkurang nya tingkat efesiensi dan efektifitas perusahaan dalam melakukan perencanaan anggarannya.

Dengan latar belakang dan fenomena tersebut diatas, maka peneliti tertarik untuk meneliti masalah yang terjadi sehingga penelitian ini berjudul "Analisis Anggaran Biaya Produksi Sebagai Alat Pengendalian Biaya pada CV. Pinang Advertising Tanjungpinang".

\section{Perumusan Masalah}

1. Bagaimana penyimpangan antara anggaran biaya produksi dengan realisasinya pada CV. Pinang Advertising Tanjungpinang ?

2. Apakah anggaran biaya produksi berperan sebagai alat pengendalian biaya pada $\mathrm{CV}$. Pinang Advertising Tanjungpinang?

\section{Tujuan Penelitian}

1. Untuk menganalisis penyimpangan antara anggaran biaya produksi dengan realisasinya yang terjadi pada CV.Pinang Advertising Tanjungpinang.

2. Untuk menganalisis peran anggaran biaya produksi sebagai alat pengendalian biaya pada CV. Pinang Advertising Tanjungpinang.

\section{Manfaat Penelitian Manfaat Ilmiah}

Hasil Penelitian ini diharapkan dapat berguna sebagai alat referensi pada penelitian serupa dimasa depan yang akan datang.

\section{Manfaat Praktis}

1. Bagi perguruan tinggi, hasil penelitian ini diharapkan dapat digunakan sebagai bahan 
referensi dan dapat menambah pengentahuan serta menambah koleksi perpustakaan yang dapat digunakan untuk kepentingan ilmiah bagi peneliti lain.

2. Bagi penulis, untuk menambah pengetahuan wawasan penulisan, terutama yang terkait dalam masalah penelitian ini, serta sebagai wadah dalam rangka menerapkan teori.

\section{TINJUAN PUSTAKA}

\section{Pengertian Anggaran}

Anggaran sebagai suatu sistem, Nampak nya cukup memadai untuk dipergunakan sebagai alat perencanaan, koordinasi dan pengendalian dari seluruh kegiatan suatu organisasi. Dengan adanya anggaran, suatu organisasi akan dapat menyusun perencanaan dengan lebih baik sehingga koordinasi dan pengendalian yang dilakukan dapat memadai pula. Dengan demikian dari gambaran tersebut dapat terasa pentingnya suatu perencanaan dan pengawasan yang lebih baik hanya dapat diperoleh manajemen dengan mempelajari, menganalisa dan mempertimbangkan dengan seksama kemungkinan-kemungkinan, alternatifalternatif dan konsekuensi yang ada.

\section{Fungsi Anggaran}

Menurut Supriyono dan Mulyadi dalam jurnal (Sutrisni, 2014) anggaran perusahaan mempunyai beberapa fungsi sebagai berikut :

\section{Fungsi Perencanaan}

Didalam fungsi ini ditetapkan anggaran sebagai alat perencanaan jangka pendek dan kesanggupan manajer pusat untuk bertanggung jawab untuk melaksanakan program atau bagian dari dalam jangka pendek umumnya satu tahun.

\section{Fungsi Koordinasi}

Anggaran berfungsi sebagai alat mengkoordinasi perencanaan dan juga dapat melakukan suatu tindakan unit atau segmen yang ada didalam suatu perusahaan agar dapat bekerja secara selaras sesuai pencapaian tujuan.

\section{Fungsi Komunikasi}

Komunkasi meluputi dengan cara penyampaian suatu informasi dilakukan manajer yang berhubungan dengan tujuan, strategi, kebijaksanaan, rencana pelaksanaan dan penyimpangan yang timbul.

\section{Fungsi Motivasi}

Didalam fungsi ini anggaran berfungsi sebagai suatu alat untuk memotivasi suatu perusahaan pelaksana yang melaksanakan tugas-tugas dalam mencapai suatu tujuan.

\section{Fungsi Pengendalian dan Evaluasi}

Pengendalian yang dipeuntukan untuk melakukan pengendalian kegiatan ataupun rencana yang telah dibuat oleh perusahaan, karna anggaran yang sudah disetujui merupakan suatu komitmen dari para pelaksana yang ikut berperan serta didalam penyusunan anggaran agar tujuan perusahaan secara umum dapat dicapai.

\section{Fungsi Pendidikan}

Anggaran juga berfungsi sebagai alat untuk mendidik para manajer perusahaan mengenai bagaimana para manajer tersebut dapat bekerja secara teliti pada pusat 
pertanggung jawaban yang dipimpinnya dan menghubungkan dengan pusat pertanggung jawaban lain didalam suatu perusahaan yang telah bersangkutan.

\section{Manfaat Anggaran}

Menurut Nafarin dalam jurnal (Sutrisni, 2014) manfaaat anggaran adalah sebagai berikut :

1. Sebagai kegiatan terarah dalam tujuan pada tujuan bersama.

2. Dapat digunakan sebagai alat penilai kelebihan ataukekurangan pegawai.

3. Dapat memotivasi pegawai.

4. Mengumpulkan tanggung jawab tertentu pada pegawai.

5. Menghindari pemborosandan pembiayan yang tidak perlu.

6. Sumber daya seperti tenaga kerja, peralatan dan dana dapat dimanfaatkan sefesien mungkin.

7. Alat pendidikan bagi para manajer.

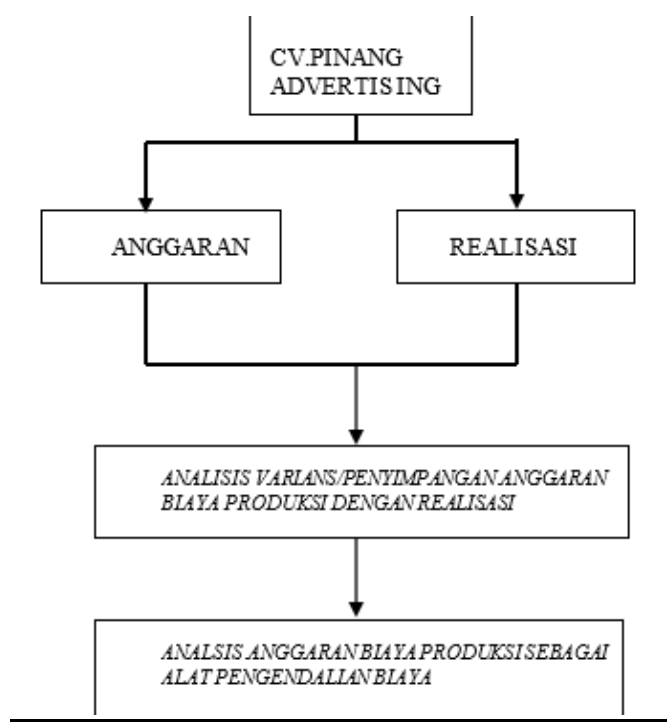

Sumber: konsep untuk penelitian 2021

Gambar 1

Kerangka Pemikiran

\section{METODE PENELITIAN}

\section{Jenis Penelitian}

Dalam penelitian ini penulis menggunakan metode deskriptif kualitatif. Penelitian deskriptif kualitatif ini akan melakukan penggambaran secara dalam tentang situasi atau proses yang yang diteliti. Menurut (Sugiyono, 2017) penelitian deskritif kualitatif adalah metode penelitian yang berlandaskan pada filsafat postpositivisme, digunakan untuk meneliti pada kondisi objek yang alamiah, dimana peneliti sebagai instrument kunci, teknik pengumpulan data dilakukan secara gabungan, analisis data juga bersifat induktif, dana hasil penelitian kualitatif lebih makan pada generalisasi.

\section{Jenis Data}

\section{Data primer}

Data primer yaitu data yang diperoleh lang dari perusahaan melaluai teknik wawancara dan obsevasi yang betujuan untuk mendapatkan informasi yang berkaitan dengan masalah penelitian untuk diolah lebih lanjut. Terkait pada rencana anggaran biaya produksi yang dibuat oleh perusahaan dengan anggaran realisasinya. Data primer dapat berupa opini secara individual atau kelompok dari hasil observasi terhadap suatu masalah.

\section{Data sekunder}

Data sekunder yaitu data yang dikumpulkan dan berhubungan langsung dengan perusahaan terkait dengan masalah yang terjadi dalam bentuk dokumentasi. Data skunder ini merupakan: struktur organisasi perusahaan, sejarah singkat perusahaan, data 
mengenai perencanaan anggaran dan realisasinya. Adapun data sekunder yang digunakan dalam penelitian ini adalah laporan perencanaan anggaran yang bersumber dari CV. Pinang Advertising Tanjungpinang tahun 2019.

\section{Teknik Pengumpulan Data}

\section{Studi pustaka}

Studi pustaka yang dilakukan penulis ini agar peneliti dapat menumpulkan segala informasi yang berkaitan dengan masalah yang akan di teliti. Segala informasi tersebut diperoleh dari buku-buku ilmiah, laporan penelitian terdahulu, buku tahunan, serta sumber-sumber lain baik cetak maupun elektronik yang berkaitan dengan topik masalah yang akan diteliti.

\section{Studi lapangan}

Teknik pengumpulan data yang dilakukan dengan datang secara langsung kelapangan kemudian untuk menggali informasinya dilakukan dengan cara sebagai berikut :

\section{Observasi}

Mengamati secara langsung terhadap objek yang ingin diteliti observasi dilakukan untuk memperoleh informasi tentang objek yang akan diteliti dengan adanya obeservasi kita akan memperoleh gambaran tentang objek penelitian tersebut.

\section{Wawancara}

Melakukan aktivitas Tanya jawab antara penulis dengan responden secara bebas baik terstruktur maupun tidak terstruktur agar peneliti dapat mengetahui informasi secara luas tentang tempat peusahaan yang akan ditelitinya.

\section{Teknik Analisis Data}

Metode analisis data dalam penelitian ini adalah analisis deskreptif kualitatif yaitupenggambaran secara dalam situasi atau proses yang diteliti. Data yang dikumpulkan dalam penelitian kualitatif biasanya berbentuk data deskriptif, yaitu yang memaparkan keadaan objek yang diteliti berdasarkan fakta didalamnya. Adapun langkah-langkah analisis data yang digunakan dalam penelitian ini adalah sebagai berikut:

1. Memaparkan data anggaran biaya produksi tahun 2019

2. Menghitung penyimpangan antara anggaran dan realisasinya.

3. Menganalisis tingkat efektivitas dari penyimpangan tersebut

4. Menganalisis pengendalian biaya

5. Menarik kesimpulan dan memberi saran

\section{HASIL DAN PEMBAHASAN}

\section{Penyimpangan Biaya Produksi}

Tabel 1

Penyimpangan Spanduk

\begin{tabular}{|c|r|r|}
\hline $\begin{array}{c}\text { Anggaran } \\
(\mathbf{R p})\end{array}$ & Realisasi (Rp) & Varians (Rp) \\
\hline $924.000 .000,-$ & $938.640 .000,-$ & $14.640 .000,-$ \\
\hline
\end{tabular}

Anggaran Biaya Bahan Baku Spanduk. Ukuran 1x5m. Maka dapat ditotalkan Anggarannya yang telah ditetapkan oleh perusahaan pada tahun 2019 sebesar Rp.924.000.000,- dan realisasinya sebesar Rp.938.640.000,-. Dari anggaran dan realisasi 
tersebut dapat disimpulkan bahwa menunjukan varians adalah favorable sebesar Rp.14.640.000,- atau dapat dipersentasikan sebesar $1,6 \%$. Terjadinya penyimpangan ini karena anggaran biaya bahan baku langsung pada Spanduk ukuran $1 \times 5 \mathrm{~m}$ yang dianggarkan mengalami peningkatan biaya produksinya sehingga biaya yang dianggarkan lebih kecil dari realisasinya.

Tabel 2

Penyimpangan Stiker

\begin{tabular}{|c|r|l|}
\hline $\begin{array}{c}\text { Anggaran } \\
(\mathbf{R p})\end{array}$ & Realisasi (Rp) & $\begin{array}{l}\text { Varians } \\
(\mathbf{R p})\end{array}$ \\
\hline $17.110 .000,-$ & $18.590 .000,-$ & $1.480 .000,-$ \\
\hline
\end{tabular}

Anggaran Biaya Bahan Baku Sticker. Maka dapat ditotalkan Anggarannya yang telah ditetapkan oleh perusahaan pada tahun 2019 sebesar Rp.17.110.000,- dan realisasinya sebesar Rp.18.590.000,-. Dari anggaran dan realisasi tersebut dapat disimpulkan bahwa menunjukan varians adalah favorable sebesar Rp.1.480.000,- atau dapat dipersentasikan sebesar 8,6\%. Terjadinya penyimpangan ini karena anggaran biaya bahan baku langsung pada

Sticker Label yang dianggarkan mengalami peningkatan biaya produksinya sehingga biaya yang dianggarkan lebih kecil dari realisasinya.

Tabel 3

Penyimpangan Stempel

\begin{tabular}{|c|c|c|}
\hline Anggaran (Rp) & Realisasi (Rp) & Varians (Rp) \\
\hline $63.125 .000,-$ & $65.735 .000,-$ & $2.610 .000,-$ \\
\hline
\end{tabular}

Anggaran Biaya Bahan Stempel $4 x 4 \mathrm{~cm}$. Maka dapat ditotalkan Anggarannya yang telah ditetapkan oleh perusahaan pada tahun 2019 sebesar Rp.63.125.000,- dan realisasinya sebesar Rp.65.735.000,-. Dari anggaran dan realisasi tersebut dapat disimpulkan bahwa menunjukan varians adalah favorable sebesar Rp.2.610.000,- atau dapat dipersentasikan sebesar $4,1 \%$. Terjadinya penyimpangan ini karena anggaran biaya bahan baku langsung pada Stempel $4 \times 4 \mathrm{~cm}$ yang dianggarkan mengalami peningkatan biaya produksinya sehingga biaya yang dianggarkan lebih kecil dari realisasinya.

Tabel 4

Penyimpangan Plakat

\begin{tabular}{|r|r|r|}
\hline Anggaran (Rp) & \multicolumn{1}{|c|}{ Realisasi (Rp) } & Varians (Rp) \\
\hline $9.675 .000,-$ & $10.105 .000,-$ & $430.000,-$ \\
\hline
\end{tabular}

Anggaran Biaya Bahan Plakat Kayu. Maka dapat ditotalkan Anggarannya yang telah ditetapkan oleh perusahaan pada tahun 2019 sebesar Rp. 9.675.000,- dan realisasinya sebesar Rp. 10.105.000,-. Dari anggaran dan realisasi tersebut dapat disimpulkan bahwa menunjukan varians adalah favorable sebesar Rp. 430.000,- atau dapat dipersentasikan sebesar $4,4 \%$. Terjadinya penyimpangan ini karena anggaran biaya bahan baku langsung pada Plakat Kayu yang dianggarkan mengalami peningkatan biaya produksinya sehingga biaya yang dianggarkan lebih kecil dari realisasinya. 
Tabel 5

Penyimpangan BTKL

\begin{tabular}{|r|r|r|}
\hline Anggaran (Rp) & \multicolumn{1}{|c|}{ Realisasi (Rp) } & Varians (Rp) \\
\hline $388.600 .000,-$ & $379.970 .000,-$ & $8.630 .000,-$ \\
\hline
\end{tabular}

Anggaran Biaya Tenaga Kerja Langsung. Maka dapat ditotalkan Anggarannya yang telah ditetapkan oleh perusahaan pada tahun 2019 sebesar Rp. 388.600.000,- dan realisasinya sebesar Rp. 379.970.000,-. Dari anggaran dan realisasi tersebut dapat disimpulkan bahwa menunjukan varians adalah favorable sebesar Rp.8.630.000,- atau dapat dipersentasikan sebesar 2,2\%. Terjadinya penyimpangan ini karena adanya pemotongan gaji pada karya yang tidak bekerja sehingga biaya yang dianggarkan untuk biaya tenaga kerja langsung lebih besar dari realisasinya.

Tabel 6

Penyimpangan BOP

\begin{tabular}{|r|r|r|}
\hline Anggaran (Rp) & \multicolumn{1}{|c|}{ Realisasi (Rp) } & Varians (Rp) \\
\hline 245.300.000,- & 251.675.500,- & 6.375.500,- \\
\hline
\end{tabular}

Anggaran Biaya Over Pabrik. Maka dapat ditotalkan Anggarannya yang telah ditetapkan oleh perusahaan pada tahun 2019 sebesar Rp.241.300.000,- dan realisasinya sebesar Rp.251.675.500,-. Dari anggaran dan realisasi tersebut dapat disimpulkan bahwa menunjukan varians adalah unfavorable sebesar -Rp. 6.375.500,- atau dapat dipersentasikan sebesar $-2,6 \%$. Terjadinya penyimpangan ini karena disebakan tidak efektifnya penggunaan biaya overhead pabrik oleh karyawan yang mengakibatkan pemborosan biaya overhead pabrik.

\section{Pengendalian Biaya}

Diketahui dengan adanya selisih favorable dari anggaran dan realisasi biaya bahan baku spanduk ukuran $1 \times 5 \mathrm{~m}$ yaitu sebesar Rp.14.640.000,- atau dipersentasikan (1,6\%). Maka anggaran biaya bahan baku spanduk ukuran $1 \times 5 \mathrm{~m}$ yang telah ditetapkan oleh perusahaan berperan dalam pengendalian biaya produksi pada CV.Pinang Advertising.

Diketahui dengan adanya selisih favorable dari anggaran dan realisasi biaya bahan baku sticker label yaitu sebesar Rp.1.480.000,- atau dipersentasikan (8,6\%). Maka anggaran biaya bahan baku sticker label yang telah ditetapkan oleh perusahaan berperan dalam pengendalian biaya produksi pada CV.Pinang Advertising.

Diketahui dengan adanya selisih favorable dari anggaran dan realisasi biaya bahan baku stempel 4x4cm yaitu sebesar Rp.2.160.000,atau dipersentasikan $(4,1 \%)$. Maka anggaran biaya bahan baku stemple $4 \mathrm{x} 4 \mathrm{~cm}$ yang telah ditetapkan oleh perusahaan berperan dalam pengendalian biaya produksi pada CV.Pinang Advertising.

Diketahui dengan adanya selisih favorable dari anggaran dan realisasi biaya bahan baku plakat kayu yaitu sebesar Rp430.000,- atau dipersentasikan (4,4\%). Maka anggaran biaya bahan baku plakat kayu yang telah ditetapkan oleh perusahaan berperan dalam pengendalian biaya produksi pada CV.Pinang Advertising.

Diketahui berdasarkan anggaran biaya tenaga kerja langsung yang telah ditetapkan 
oleh perusahaan yaitu terdapat selisih yang dimana anggaran yang telah ditetapkan lebih besar dari realisasinya atau favorable yaitu sebesar Rp.8.630.000,- atau dipersentasikan $(2,2 \%)$. Maka dapat digunakan sebagai alat pengendalian biaya dikarenakan dalam melakukan produksi jika biaya yang sudah dianggarkan oleh perusahaan lebih besar dari realisasinya akan meminimalisir peningkatan biaya sesungguhnya.

Diketahui dengan adanya selisih unfavorable dari anggaran dan realisasi biaya overhead pabrik yaitu sebesar Rp.6.375.000,atau dipersentasikan (2,6\%). Maka anggaran biaya overhead pabrik yang telah ditetapkan oleh perusahaan belum berperan dalam pengendalian biaya produksi pada CV.Pinang Advertising.

\section{PENUTUP \\ Kesimpulan}

Berdasarkan analisis data dan pembahasan mengenai kesesuaian penyajian laporan anggaran dan realisasi biaya produksi pada CV.Pinang Advertising Tanjungpinang terrdapat beberapa kesimpulan, yaitu sebagai berikut:

1. Pada CV. Pinang Advertising laporan penyusunan anggaran dibuat sesederhana mungkin dan disajikan dalam bentuk buku yang dimana pada biaya bahan bakunya dipisah pada masing-masing produk. Kemudian laporan penyusunan anggaran yang dibuat oleh bagian kenuangan tersebut disampaikan kepada owner untuk sebagai informasi perusahaan. Anggaran dibagikan kepada bawahan atau karyawan untuk dilaksanakan proses produksi. Penyusunan anggaran produksi dimulai dari penyusunan jumlah produksi kemudian penyusunan biaya bahan baku, biaya tenaga kerja langsung dan biaya overhead pabrik.

2. Hasil anggaran biaya produksi pada CV.Pinang Advertising memberikan selisih dimana pada anggaran biaya bahan bakunya menunjukan hasil anggaran yang telah ditetapkan oleh perusahaan lebih kecil daripada realisasinya (favorable). Anggaran biaya tenaga kerja langsung yang telah ditetapkan perusahaan menujukan hasil yang dimana anggaran yang telah ditetapkan lebih besar dari realisasinya (favorable). Anggaran biaya overhead pabrik yang telah ditetapkan oleh perusahaan menunjukan hasil yang dimana anggaran biaya overhead pabrik yang telah ditetapkan oleh perusahaan lebih kecil dari realisasinya (unfavorable).

3. Pada CV.Pinang Advertising belum memberikan peranan dalam pengendalian biaya. Hasil dari selisih varians pada biaya overhead pabrik belum berperan baik yang dimana terjadi penyimpangan anggaran yang telah ditetapkan lebih kecil daripada realisasinya (unfavorable). Itu dikarenakan pada pada biaya overhead pabrik itu dikarenakan tidak efektifnya penggunaan biaya overhead pabrik oleh karyawan yang mengakibatkan pemborosan biaya overhead pabrik. 
Sedangkan biaya ahan baku penjualan dan biaya tenaga kerja langsung dapat digunakan sebagai alat pengendalian biaya yang dimana menunjukan hasil anggaran yang telah ditetapkan lebih besar dari realisasinya (favorable), dikarenakan realisasi anggaran penjualan biaya bahan baku langsung lebih kecil anggaran biaya bahan baku langsungnya, dalam melakukan produksi jika biaya yang sudah dianggarkan oleh perusahaan lebih besar dari realisasinya akan meminimalisir peningkatan biaya sesungguhnya.

\section{Saran}

Berdasarkan kesimpulan diatas, penulis mengusulkan beberapa saran kepada pihak CV.Pinang Advertising sebagai:

1. Bagian keuangan perusahaan dalam menetapkan anggaran biaya produksi harus lebih baik lagi.
2. Dalam anggaran yang telah ditetapkan oleh perusahaan yang mengalamai selisih dimana anggarannya lebih kecil dari perusahaan (unfavorable) baik pada biaya bahan baku maupun biaya overhead pabrik sebaiknya dalam penyusunan anggaran harus memperhitungkan factor-faktor yang tidak terduga seperti peningkatan penjualan pada tahun selanjutnya atau tin.gkat penggunaan biaya overhead pabrik yang tidak efektif.

\section{DAFTAR PUSTAKA}

Bustomi, B., \& Nurlela., 2013. Akuntansi Biaya (4th ed.). Jakarta: Mitra Wacana Media.

Carter, W. K., 2017. Akuntansi Biaya. Jakarta: Salemba Empat.

Delvi, S. Y., 2010. Analisis anggaran biaya produksi sebaga alat perencaan dan pengawasan pada PT. Perkebunan Nusantara V Bukit Selasih-Riau.

Dewi, S. P., \& Kristanto, S. B., 2013. Akuntansi Biaya. IN MEDIA. 